\title{
Improving the Volk: Leon Kellner and the Jewish Toynbee Hall Movement (1900-39)
}

David Rechter

\begin{abstract}
The Jewish Toynbee Hall movement - part moral crusade, part adult education-has almost entirely escaped the attention of historians, as has its prime mover, Leon Kellner. Modeled on London's Toynbee Hall, the first Jewish Toynbee Hall opened in Vienna in December 1900; within a few years, others opened across Habsburg Austria and in Germany and Romania. A Zionist project, the Toynbee Halls were taken over by Bnai Brith in Germany and Austria but remained in nationalist hands further east, part of a Jewish public sphere-reading rooms, newspapers, libraries, lecture halls— that produced, consumed, and disseminated Jewish knowledge and culture. Kellner, one of Theodor Herzl's first and closest confidants, was a Galician who became a renowned Shakespeare scholar, public intellectual, and politician. The article aims to begin to write the Jewish Toynbee Halls and Kellner back into history.
\end{abstract}

Key words: Toynbee Hall, Vienna, Leon Kellner, Bnai Brith

I

n early December 1900, Theodor Herzl spoke to a crowded hall of some 150 people in the working-class district of Briggitenau suggestion, those inside made way for an equal number waiting outside-not once but twice. In the "musty air" of this "narrow, quiet street," where the "glamour and affluence of the city had not yet penetrated," the leader of the Zionist movement was lending his

David Rechter, "Improving the Volk: Leon Kellner and the Jewish Toynbee Hall Movement (1900-39)," Jewish Social Studies: History, Culture, Society n.s. 24, no. 3 (Spring/Summer 2019): 51-79. Copyright (C) 2019 The Trustees of Indiana University. doi: 10.2979/jewisocistud.24.3.03 
support to the opening of a new institution, the Jewish Toynbee Hall, the first of its kind in Europe. Speaking before Herzl was Leon Kellner, Toynbee Hall's prime mover and guiding spirit. Here, said Kellner, "the prosperous and educated would devote a few hours of

Jewish

Social

Studies

Vol. 24

No. 3 their time to those less fortunate and less educated in order to fortify them morally and spiritually for the struggle of the following day." 1 Kellner hoped the Toynbee Hall would be an "oasis in the desert" for the Jewish poor, the "peddlers, junk dealers and tradesmen [who] for a few hours might escape the dreadful solitude of the big city and realize they were not alone in the world." ${ }^{2}$ Vienna's Jewish Toynbee Hall was an immediate popular success and became the launching pad of a movement that spread quickly to other Habsburg landsBohemia, Moravia, Galicia, Bukovina-and also further afield to Germany, Romania, and the Netherlands. Its mixture of accessible lectures, musical and literary performances, children's entertainment, adult-education courses, and food, all provided free of charge, proved a winning formula.

The Jewish Toynbee Halls have almost entirely escaped the serious attention of historians, as has Kellner, whose life and work reflect some fundamental themes of post-Enlightenment Habsburg Austrian Jewish history, including the relationship of Jews as a collective to other minorities and peoples in the empire; the need to belong to the empire, which led to an identification with and a reliance on the state; the tension between great opportunity and great constraint for individuals and the collective-what has been called, in the German context, "the half-open door"; ${ }^{3}$ regional diversity (Kellner lived in four different crownlands); and division along an east-west axis. This last theme conformed with a broader discourse that cast Jewish eastern Europe as lacking the "modern" attributes of the west: eastern European Jews were numerous, poor, Orthodox, Yiddish-speaking, and unacculturated, whereas Jews in western Europe were fewer, more homogeneous, religiously moderate, middle-class, and better acculturated. Sigmund Kaznelson, a Prague Zionist intellectual and activist, wrote in 1921 that Austrian Jewry had been "a union of an entirely western with an entirely eastern Jewry."

The Toynbee Halls, similarly, were part of a larger phenomenon: a kind of Jewish public sphere, in particular in central and eastern Europe. In much the same fashion that other ethnic, national, and religious groups promoted and sustained particularist traditions in this region, so too Jews created a network of institutions that produced, consumed, and disseminated Jewish knowledge and culture. The Jewish public sphere was made up of adult education, people's 
universities, literary and cultural societies, reading rooms, libraries, newspapers, and journals, all of which relied on Jewish society for owners, operators, functionaries, activists, speakers, teachers, writers, performers, themes, and audiences. ${ }^{5}$ In and of itself, this kind of activity was not new. Whether in the first half of the nineteenth century in Germany or the final decades of tsarist Russia, Jews banded together socially, culturally, and economically in distinctive ways that went well beyond ties of religion. ${ }^{6}$ Beginning in the 1870 s in the Habsburg lands, the nature and scope of associational life expanded exponentially from the rather narrow bourgeois template that had been laid down in the period preceding the 1848 revolutions. On the one hand, this was a function of the greater freedom offered by a liberal regime after the dissolution of neoabsolutism; on the other, the nationalist wave that took hold in the 1880s was accompanied by a surge in activism. ${ }^{7}$ Though Jews participated individually in the general expansion, having been emancipated in 1867, they also carved out an identifiable collective domain of their own, an ethnic milieu powered by the addition of newer nationalist impulses to long-standing ethnic and religious bonds.

The Jewish Toynbee Halls were characteristic of this ethnic milieu in that they adapted a model from surrounding society to the particular needs of Jews. This was not a retreat into isolation or exclusivity; it was, rather, a form of partial self-segregation for the purposes of ethnic consolidation and comfort, the need for which arose from both developments internal to Jewish society and external pressures. Shaped by this combination of centripetal and centrifugal forces, the Jewish Toynbee Halls reflected the dialectic that shaped Austria's Jewish public sphere, whose existence was possible because this was a relatively open, imperfectly functioning democracy; its existence was necessary because of the powerful constraints and difficulties faced by Jews there. Neglected fragments of the Jewish past, the Jewish Toynbee Halls and Kellner's life and work are case studies not only of the considerable vitality and pluralism of imperial Austrian civil society but also of its powerful illiberal, exclusionary tendencies. ${ }^{8}$

$* * *$

Toynbee is not a name generally thought of with particular affection in Jewish collective memory. Most often it is associated with Arnold Joseph Toynbee (1889-1975), who in his 12-volume A Study of History called the Jews an "extinct society" and "a fossil" of Syriac civilization and drew a moral equivalence between Zionism, the state of Israel, 
and Nazism. ${ }^{9}$ But there is a lesser-known and happier connection between Toynbee and the Jews: Arnold Toynbee (1852-83), uncle of the more famous Arnold Joseph Toynbee. The older Toynbee was an economic historian and Fabianist social reformer, commonly cred-

Jewish

Social Studies

Vol. 24

No. 3 ited with popularizing the term Industrial Revolution. In the course of his political and social activism, he befriended Canon Samuel Barnett and his wife Henrietta, who had moved to London's East End in the early 1870 s in order, as Henrietta later wrote, "to work for, to teach, and learn of, the poor."10 What they found there, she noted, was "an Irish quarter and a Jews' quarter ... [with] whole streets ... given over to the hangers-on of a vicious population, people whose conduct was brutal, whose ideal was idleness, whose habits were disgusting.... Robberies, assaults, and fights in the streets were frequent." ${ }^{11}$ Far from deterring the Barnetts, who were searching for an outlet for their reforming zeal, "Outcast London" suited their purposes well. This might have been what William Booth, the founder of the Salvation Army, called "darkest England," but it was the Barnetts' devout wish to live and work here, to lead the way in improving an environment that Henrietta believed "lent itself to every form of evil, to thriftless habits, to untidiness, to loss of self-respect, to unruly living." ${ }^{12}$ Toynbee enthusiastically joined the Barnetts in this work, spending extended periods in Whitechapel.

At the end of 1884, the Barnetts established their first "settlement," a purpose-built house modeled on an Oxford college, in which university graduates lived. The aim of Toynbee Hall, as they called the house in memory of the recently deceased Arnold, was for the graduates to "share themselves with their neighbors" and to be "a club-house in an industrial district ... where the residents may make friends with the poor." ${ }^{13}$ Forging friendships across the class divide was perhaps asking too much of both sides of the equation; nonetheless, the residents, all male and mostly Oxford and Cambridge graduates, launched themselves into local life, organizing and hosting an array of innovative educational, cultural, and social events, engaging politically in trade unions, schools, and boards of guardians, dispensing legal advice, and conducting pioneering research into social deprivation. ${ }^{14}$

News of the experiment spread quickly. Within a few years it had been noted in Baedeker's London guide, and a number of similar projects had been founded in the city. This was the beginning of the settlement movement, which spread first across Britain and then to the United States and Canada. ${ }^{15}$ Neither ideologically nor organizationally coherent, the movement was loosely bound by a commitment to bridging social differences. In the most general terms, 
a settlement was "an outpost of culture and learning, as well as a community center; a place where the men, women, and children of slum districts could come for education, recreation, or advice, and a meeting place for local organizations." ${ }^{16}$ Although Toynbee Hall was often called the "mother of all settlements," it was atypical in many respects. Most of the London settlements, for example, aligned themselves denominationally (with Methodists, Quakers, or Catholics), whereas Toynbee Hall, if imbued with a religious ethos, was nondenominational and open to all; it attracted "seekers and doubters, not the men of faith." ${ }^{17}$ At work in Toynbee Hall and other settlements was an eclectic compound of late-Victorian ideas about religion, political reform, social service, education, and the power of culture to civilize and elevate morally. ${ }^{18}$ Those of a more radical disposition were unimpressed by what they saw as paternalism and noblesse oblige; the anarchist Emma Goldman dismissed settlements as "teaching the poor to eat with a fork." ${ }^{19}$ For their part, Toynbee Hall's residents hoped to blunt the worst excesses of the East End's overcrowding, inadequate sanitation, poverty, unemployment, crime, vice, and squalor; they wanted to ameliorate lives that were, in their eyes, tragically blighted.

By the early 1880s some 120,000 Jews lived in the East End, both eastern European immigrants and those born in England. Whitechapel, where Toynbee Hall was located, had the greatest concentration and most rapid increase of immigrants; in 1901, some 37 percent of its residents were "foreign." ${ }^{20}$ From its inception, then, Toynbee Hall was surrounded by Jews, although this was not something that it addressed directly in its work or rhetoric. Barnett did, however, comment in 1893 that because Toynbee Hall was "unsectarian," its sole Jewish resident, Harry Lewis (later a Reform rabbi), worked "among the general poor as well as his own." Barnett regretted the "absence of reverence" he detected among Jews; they ought to "cultivate higher ideals." They were also, he felt, in need of more sanitary inspectors and physical education. "The conditions of East End life contain many of the elements of a Judenhetze [incitement against Jews], " he warned. ${ }^{21}$ Toynbee Hall's muted religiosity made it a welcoming environment for Jews, who made up a substantial proportion of students taking classesperhaps one-quarter by the first decade of the twentieth centuryand also provided financial support and assistance with teaching. As an editorial in the Jewish Chronicle, Anglo-Jewry's paper of record, put it in 1894, Jews had "derived much advantage" from $\mathrm{it}^{22}$ - so much so that the idea of establishing a Jewish analog was soon raised by the banker and philanthropist Samuel Montagu (Baron Swaythling), the 
Liberal member of Parliament for Whitechapel from 1885 to 1900. Montagu, an Orthodox Jew who reportedly told Theodor Herzl in 1895 that he felt himself "more an Israelite than an Englishman," was at the forefront of Jewish welfare work in the East End. ${ }^{23}$ In 1890, he

Jewish

Social Studies

Vol. 24

No. 3 suggested that a new institution, modeled on Toynbee Hall, should be created to cater to the welfare and the educational and cultural needs of immigrant and poor Jews in the East End. The existing Toynbee Hall, for all its fine work, was neither equipped nor inclined to take on such a task. ${ }^{24}$ Montagu found support from another communal notable, Chief Rabbi Hermann Adler, who saw a Jewish Toynbee Hall as an ideal instrument for tackling "the pressing duty of civilising and anglicising our foreign brethren." 25

To civilize and to Anglicize-conceived as two sides of the same coin-remained the key impulses behind the project. The Jewish Toynbee Hall promised to be a

center of light in a gloomy district, a clearing in a forest, a fountain in a desert.... [These] are Oriental images which suggest the sort of work to be done by the settlement of a colony of active, benevolent and God-fearing persons, imbued with true Jewish piety, and genuine English enlightenment in the midst of a necessitous and backwards population. ${ }^{26}$

In an editorial, the Jewish Chronicle hoped that a Jewish Toynbee Hall would "bring brightness into cheerless homes, and infuse hope into dreary lives." ${ }^{27}$ It was envisaged as a central element of the so-called East End Scheme, an ambitious plan to build an institutional hub and community center for the Jews of the area. Hopes for this scheme, and for a Jewish Toynbee Hall as part of it, were dashed as the proposal became mired in larger factional disagreements among London's Jewish leaders. ${ }^{28}$ The idea of a Jewish Toynbee Hall periodically resurfaced, even on occasion after World War I, but nothing came of it. It was, however, to find an echo across the channel, where it was carried by Leon Kellner.

Kellner (1859-1928), an Anglophile scholar, teacher, and essayist, had spent nearly every summer since 1885 in London, passing the bulk of his time at the British Library (his annual pilgrimage, as he called it, from his Vienna home).$^{29}$ On one such trip, in 1895, he visited Toynbee Hall and found much to like. It was, he thought, a "peculiarly English" institution that served the "interests of the people" well. He carefully noted the social composition of its clientele and the diversity and quality of its programs, and he was impressed 
by the "enthusiasm and goodwill" of its young workforce ${ }^{30}$ Could this "peculiarly English" formula succeed elsewhere? Kellner believed that with appropriate modification transplantation was possible, and a few years later he was in a position to make the attempt.

Born in Tarnów, Galicia, a city in which Jews made up at least 40 percent of the population for most of the second half of the nineteenth century, Kellner was destined, so his parents hoped, for a glittering rabbinical career. ${ }^{31}$ Attending heder from the age of three, and studying privately from 13 , he was regarded as a talmudic prodigy, but an adolescent rebellion set him on a different path. Among other sins, he taught himself Latin, read secular literature, and dared to contradict the great eleventh-century scholar Rashi, which earned him several beatings from his father. Trying to keep him within the fold, his parents reluctantly permitted him to attend Zacharias Frankel's newly opened Jewish Theological Seminary in Breslau (Wrocław), which until the 1870s offered an upper-level Gymnasium education in addition to advanced rabbinical training. As if to emphasize the parting of the ways, Kellner transformed himself from a Hasidic Jew into a German-style modern Orthodox Jew by trimming his peyes (sidelocks) and replacing his long black coat with a shorter jacket. But in Breslau, too, he chafed at the restrictions of the curriculum and the sterility of the pedagogy, finding both reminiscent of his experience in Tarnów (Heinrich Graetz was a particular disappointment as a teacher). After a year, he moved to Bielitz (Bielsko), on the Silesian-Galician border, graduating with distinction two years later from the local Gymnasium. From there he headed immediately for Vienna and the empire's premier university to study philology and comparative linguistics.

From heder in Tarnów to university in the imperial capital in the space of a few years was a dramatic ascent. In 1880, only the tiniest fraction of the population (well below 1 percent) attended secondary school and university, although Jews were disproportionately represented at both. ${ }^{32}$ The two years in Bielitz were decisive. As his wife Anna, whom he met there, later wrote, he began at the school a "restless, skeptical, querulous hothead" and emerged two years later "happy, more content, and full of confidence in the future." Kellner himself wrote that he had made "a transition from purely Jewish life and thought to free-thinking." ${ }^{33} \mathrm{He}$ earned his doctorate in 1883, with a study of verb syntax in Shakespeare, and began to work soon after as a part-time teacher of English, French, and religion (Judaism) at secondary schools in Vienna. ${ }^{34}$ At the same time, he launched what was to become a 40 -year career as an essayist for the quality press, 
publishing a piece entitled "Schopenhauer as Philologist" followed by feuilletons on the seventeenth-century French dramatist Pierre Corneille (marking the two-hundredth anniversary of his death) and the contemporary German literary scholar and writer Eduard

Jewish

Social Studies

Vol. 24

No. 3 Engel, a German Jew who later developed extreme German nationalist views. ${ }^{35}$ This spread of subject matter, combining literature, history, and politics, remained typical of Kellner's essays, for which he was later lauded as "a master stylist in the most noble German tradition." 36

With his paramount goal an academic post in Vienna, Kellner pursued his research and published at an impressive pace. Shakespeare was his primary focus, but - as with his essays-he cast a wide net, writing philological studies of English-language history and development; critical editions of medieval English texts; textbooks on historical grammar; studies of Anglo-Saxon and Middle English proverbs and of contemporary English poets and novelists; translations of English fairy tales for children (with his wife); and a volume of observational pieces recording a year spent in London at the end of the 1890s. ${ }^{37}$ By the turn of the century, his reputation was well established, both at home and abroad. His annual visits to London had made him a valued friend and colleague of many in the cultural elite of late-Victorian England, and he became a prominent mediator between English and Austrian/German culture. Among his acquaintances, for example, were Ramsay Macdonald (the future British prime minister was a "regular visitor" to Toynbee Hall in London), Rudyard Kipling, Israel Zangwill, and George Bernard Shaw, and he was in part responsible for bringing Shaw's work to the continent. ${ }^{38}$ Appointed as a docent at the University of Vienna in 1890, he had no illusions about his prospects in the capital, believing that antisemitism posed an insuperable obstacle: "A chair in Vienna," he wrote in 1899, "would be a miracle." 99 The call came, instead, from the empire's east. In late 1901, the FranzJoseph University in Czernowitz, the capital of Bukovina, proposed the creation of a chair in English philology and suggested that Kellner be appointed to it. He took up the post in 1904, retaining it until 1918 and the collapse of the Habsburg state. ${ }^{40}$

This was acculturation and success but not assimilation. Certainly Kellner was one of the great and good of the last two decades of imperial Austria: the press noted his daughters' marriages (his eldest daughter married Walter Benjamin), recorded his presence at events, and reviewed his publications. ${ }^{41}$ But if, as he had written, he had long since left the "purely Jewish" world of thought, he had by no means renounced it. He corresponded occasionally in Yiddish, continued 
to read Hebrew texts, and for a number of years pursued a quixotic project to locate the origins of select Shakespearean phrases in Pirkei Avot. ${ }^{42}$ Most obviously, though, this was evident in his political activism. An important figure in the first years of political Zionism, Kellner was an early confidant of Theodor Herzl, who in 1898 called him "my closest and most beloved friend." ${ }^{33}$ Herzl thought Kellner a writer and critic of the first order, seeking his advice on the first English translation of Der Judenstaat ("I am an amhorez [ignoramus] in English," Herzl wrote), appointing him as his literary executor, and asking him on more than one occasion to be editor of the Zionist movement's flagship newspaper, Die Welt. ${ }^{44}$ He sought Kellner's view on drafts of his novel Altneuland (in which a thinly disguised Kellner appears)commenting that "[a] word from you will either uplift me or devastate me"-and went to considerable lengths to try to arrange a post for him as an editor for English literature and politics at the Neue Freie Presse, where Herzl was editor of the prestigious feuilleton section. ${ }^{45}$ As for his role in the Zionist movement, Kellner possessed a quality that Herzl knew he lacked himself: a kind of Jewish authenticity. As Kellner wrote to him in 1899, semi-ironically: "You need a ghetto Jew who can speak the ghetto's language. You're not one. But I am.... I can speak and write in that ghetto spirit that you don't understand." Like many of Herzl's relationships, the friendship was not always smooth. Kellner told Herzl that he was "overbearing," "mistrustful," and behaved like "an enlightened despot." "I have spent precious hours in your company," he wrote, "but do you know how often I've said to myself: to help and be of service to this man is a joy; [but] to be a true and genuine friend is difficult." 46

Following Herzl's death in 1904, Kellner retreated temporarily from frontline Zionist work. Although Herzl once chided him affectionately as an "impractical scholar," in practice he valued Kellner's judgment and tact, asking him to stand as a Zionist candidate in the imperial parliamentary elections of 1897 and relying on him for discreet diplomatic work for the movement in London and Vienna. ${ }^{47}$ Kellner was certainly not temperamentally inclined to political activism, telling Herzl at one point that the Zionist movement was "merely noise" (to which Herzl's cryptic response was that "the whole of world history is nothing but noise"), but he proved to be an adept politician. ${ }^{48}$ In Czernowitz, where he soon reentered the political fray, he revived and led Bukovina's moribund Zionist movement and was elected on a Jewish nationalist ticket to the regional parliament (Landtag), a position he held until the war. In this, Kellner exemplified the dualtrack approach of Austrian Zionism first developed in Galicia: the goal 
remained Palestine but the problems of the here and now demanded attention. ${ }^{49}$ In 1896 he wrote to a friend,

I am a good Austrian in every respect, rejoicing and suffering with the fatherland.... I live and work with Christians, I teach Christian children and every day I am ... filled with pride and satisfaction that I have been permitted to breach the barriers of prejudice, despite all the impediments of birth, education and the malevolent Zeitgeist [i.e., antisemitism]..$^{50}$

But not everyone is so fortunate, he pointed out, asking, "How can I know what the future holds for my children?"51 As he declared more than a decade later, "There is only one way to solve the Jewish Question.... We [the older generation] might not make it to Palestine ... but if we do not, our children will; and if not our children, then I know with certainty that our grandchildren will." ${ }^{52} \mathrm{He}$ knew whereof he spoke. Two of his children had settled in Palestine by the early $1930 \mathrm{~s}$, as did his wife later in the decade.

For a man who believed Habsburg Austria to be a "historical necessity," the postwar, post-Habsburg decade in Vienna was challenging. ${ }^{53}$ Denied a university post, in large part due to antisemitism, he nonetheless pressed ahead with research, publishing two major Shakespeare studies. ${ }^{54}$ Outside the familiar spheres of writing and teaching, he found a surprising source of consolation. Toward the end of 1919, President Karl Seitz, a Social Democrat, created a position for him as presidential liaison to the Anglophone world, a vaguely defined post that he retained until his death in $1928 .{ }^{55}$ Seitz's successor as president, Michael Hainisch, praised Kellner's "invaluable service" as translator, teacher, and unofficial diplomat, in particular his work with Herbert Hoover's American Relief Administration in Vienna, a principal source of food and aid in the immediate postwar years. Hainisch, who described Kellner as an "unforgettable friend," was instrumental in Kellner being awarded the honorific title of Hofrat (court councillor) in 1923. "In my long life," wrote Hainisch, "I have met few equally distinguished men." 56

\section{$* * *$}

In September 1900, Kellner proposed that the Zionist Organization establish a Jewish Toynbee Hall under its auspices in Vienna. ${ }^{57}$ Impressed with the London original and aware that a Jewish version had been stillborn, he thought a more modest incarnation might 
take root in Vienna, home to Herzl's new Zionist movement and to a large and growing number of impoverished and culturally deprived Jews. ${ }^{58}$ Kellner saw a Jewish Toynbee Hall as an inclusive, pluralist platform for his Fabianist-inflected commitment to social reform and education. ${ }^{59}$ For the Zionists, it offered an opportunity to reach out beyond their core of support, if in a relatively concealed guise. Just as London's Toynbee Hall was the "mother of all settlements," so too could Vienna's Jewish Toynbee Hall act as a model for others to emulate. This was in keeping, as the longtime secretary of Vienna's Toynbee Hall wrote, with a loose reading of Herzl's 1898 injunction to "conquer the communities," in this instance working among and for the people rather than targeting the leadership echelon of the formal representative organizations. ${ }^{60}$

Why did Kellner suggest a Jewish rather than a regular Toynbee Hall? First and foremost, it was because of antisemitism. Vienna was not London, Kellner wrote, and the relatively straightforward social mixing of Jews and others he had witnessed in the East End would represent an "inconceivable gamble" in Vienna; the mere fact that Jews were the founders and sponsors would make such an institution "suspect" to many Viennese. Given that similar "altruistic" projects, nominally open to all, in fact excluded Jews entirely, it was preferable to focus on the needs of the Jewish underprivileged and poor. ${ }^{61}$ The goal, for Kellner, was to help "our tradesmen, hawkers, peddlers, clerks, brokers [who] crave to forget ... the tragedy of isolation in the wasteland of the big city, to feel part of a whole for a few hours and to satisfy the traditional Jewish need for intellectual nourishment." ${ }^{\prime 2}$ He proposed a division of labor between the wealthy and the learned: "the prosperous and educated should devote a few hours of their day to the poor and less educated, to fortify them morally and intellectually for the next day's struggle." If the initial inspiration came from London's Toynbee Hall, Kellner pointed also to Jewish antecedents: "The need for sociability and intellectual stimulation is an age-old element of the Jewish character." ${ }^{63}$ His project was but a new link in a long chain of institutions that catered to this need. "Long before Arnold Toynbee," he argued, the Jews of eastern Europe "had recognized the need for Toynbee Halls and had accordingly established countless Toynbee Halls" in the form of kloyzn (private study circles), synagogues, and batei midrash. He depicted these as sites of radical social equality, where the mundane distinction between rich and poor had been erased, an aspiration that lay at the heart of the Jewish Toynbee Hall. ${ }^{64}$ Here, all men and women would be welcome, and all "should feel at home." ${ }^{65}$ 
This was, at least in part, also a moral crusade. Echoing the paternalistic tones of the settlement movement, the idyllic future Vienna Toynbee Hall was contrasted with "one of the saddest aspects of life in the metropolis," the tendency of Jewish youth in Vienna to frequent cabarets, dance halls, and cafes, entertainments that had "ruined more lives than tuberculosis or plague." An alternative that combined edifying entertainment-classical music performances, literary readings, poetry recitals-with demanding but accessible intellectual fare could, Kellner hoped, draw Jews away from such "toxic sites" of "brazenness and frivolity." ${ }^{66}$ The settlement milieu was reflected too in the impulse to educate. A key instrument in the drive to reduce social isolation, bridge class divides, and offer cultural "improvement," adult education (commonly called Volksbildung) had flourished since the 1870s in Vienna and elsewhere in Austria, reaching audiences of hundreds of thousands by the turn of the century. This was in turn part of a pan-European development, often embedded in socialist or nationalist movements ${ }^{67} \mathrm{~A}$ small $\mathrm{cog}$ in this large wheel, the determinedly unsystematic - and strictly apolitical-program of popular education that lay at the heart of the work of the Jewish Toynbee Hall was a precursor to the expansion of Jewish adult education in the years following World War I, particularly in Weimar Germany. ${ }^{68}$

Although it was a Zionist initiative, the Vienna Hall insisted on political neutrality in its programs and self-presentation, and the Zionist Organization, while happy to claim credit for the idea, provided little in the way of financial or institutional support. From the outset, Toynbee Hall was entirely reliant on volunteers for every facet of its work and dependent on the generosity of donors for survival. Its template for activity was simple and unvarying: on weeknights from October to March, a lecture and discussion was held, followed by a pause for refreshment and either a second lecture or discussion or a musical or literary recital. Friday evenings were reserved for a talk on biblical themes, Saturday evenings for concerts, and each fortnight a children's party was held on Sunday. From April to September, adult-education courses were offered in English, Hebrew, French, German literature, mathematics, accountancy, shorthand, and typing. All of this was provided free of charge ${ }^{69}$ Success was immediate. The hall, able to accommodate some 150 people, was regularly filled to capacity, and it was soon apparent that demand exceeded supply; overflow crowds were common, on occasion requiring a police presence to maintain order. Within a year, new and more spacious premises were found (still in the working-class Briggitenau district), and attendance increased accordingly. ${ }^{70}$ 
The first years saw up to two hundred lectures annually in the winter months, on medicine, natural sciences, history, literature, psychology, philosophy, economics, and legal affairs, as well as a variety of Jewish-themed topics, complemented by up to 60 performances. The summer courses were similarly successful, with between 20 and 50 students enrolled in each; the children's parties drew two hundred 5-to-12-year-olds from across Vienna. ${ }^{11}$ This amounted to a cumulative clientele of thousands, made up of equal numbers of men and women aged 20 to 70 -commercial employees, small traders, peddlers, porters, day laborers, students, and the unemployed. ${ }^{72}$ The scale of such an undertaking required a prodigious outlay of time and energy from a devoted volunteer workforce. Tasks were divided to some extent along gender lines: men took charge of the lecture program; culture, adult-education courses, and publicity were shared; women were responsible for the children's events and for the catering. This last, it was often noted, was the glue that held everything together, demanding a greater degree of daily organization and effort than all else. Many in the audience, the "poorest of the poor" as one of the founders described them, were in dire need of the complimentary tea, cake, and biscuits. ${ }^{73}$

The idea was quickly taken up elsewhere. In the months following the Vienna opening in December 1900, new Toynbee Halls opened in Brno, Moravia's largest city; in eastern Galician Drohobycz; and in Braila, in southeastern Romania. A year later, these had been joined by Prague, Bucharest, Lwów (Lemberg), Amsterdam, and Czernowitz, and planning was underway in Berlin. ${ }^{74}$ Testimony to the success of Zionist insistence that the Toynbee Halls were an apolitical undertaking, the philanthropic association Bnai Brith set up a community center, a Jewish Toynbee Hall in all but name, in Hamburg in late $1901 .{ }^{75}$ In fact, so persuasively "non-Zionist" was the concept that in the following years Bnai Brith-a self-styled ethical elite with a liberal, affluent membership devoted to good works and virtuous citizenship and with little sympathy for Zionism-came to play a crucial role in developing and sustaining Toynbee Halls in Germany and Austria. ${ }^{76}$

The Prague Jewish Toynbee Hall, for example, was a joint venture of nationalists and liberals from its inception in 1902, directed initially by Ludwig Bendiener, a prominent German liberal and a leader of the Jewish Religious Community (Kultusgemeinde), and then by Philip Falkowicz, at one time head of the city's German Merchants' Club. ${ }^{77}$ Bnai Brith assumed sole responsibility in 1905, although little changed under the new ownership. Operating on a more modest scale than its Vienna counterpart, the Prague Toynbee Hall held 
weekly lectures (Franz Kafka gave a reading there in December 1913, describing the audience as "exemplary"), ran a library and reading room, and offered adult-education courses in shorthand and classes in French, Czech, and Hebrew language until $1915 .^{78}$ In Berlin, too,

Jewish

Social Studies

Vol. 24

No. 3 Bnai Brith took over the Jewish Toynbee Hall in 1904, putting an end to two years of work with the Zionists that had yielded little. Cleaving to the Viennese model, Bnai Brith hoped "to bring a glimmer of light into the dismal lives of the poorest of the poor by offering them ... the spiritual uplift vouchsafed by art and learning." 79 The "poorest of the poor" (a repeated refrain) was made up here of glaziers, upholsterers, house painters, tobacco workers (in particular young Russian women), seamstresses, locksmiths, tradesmen, clerks, milliners, cobblers, and peddlers. And, as in Vienna, it was hoped that the "dignified and respectable setting" of Toynbee Hall would steer impressionable youth away from the "moral perils of the metropolis." ${ }^{80}$ Traces of Kellner's ideas were also to be found in Bnai Brith's depiction of Toynbee Hall as heir to a long chain of venerable Jewish ideals and institutions, suggesting a direct line between synagogue, study house, yeshiva, and their new "institute for adult education."

This "temple of social and ethical progress" ${ }^{2}$ in Berlin continued to grow steadily until World War I. By 1909, when it moved to a larger site, more than seven hundred lectures and three thousand brief musical and literary performances had taken place. ${ }^{83}$ The nightly diet of enlightenment and food in the winter months-unlike Vienna, there were no summer courses-was frequently received with gratitude. "Only in the evenings here," wrote a "poor and almost blind" 50-year-old Polish-born tradesman, "can I find consolation, joy and education." For a 40-year-old Russian-born woman, abandoned by her husband and eking out a living as a florist, Toynbee Hall was a "great comfort" and a "priceless achievement." A 50-year-old seamstress called it a "great blessing, particularly for unmarried people.... Toynbee Hall is my sole recreation in the long winter nights." A 50-year-old furrier from east Prussia wrote simply: "I have seen better days and have had happier times. At Toynbee Hall, I can find something of these again." A 50-year-old tailor succinctly captured the sentiments of a good portion of the Toynbee Hall faithful: "It is as though everyone here is part of a large family." 84 This would have been music to Kellner's ears.

In Vienna, the original Jewish Toynbee Hall followed a similar route. Despite the considerable popularity and acclaim it enjoyed in its first years, its finances were always precarious. Neither the warm words of appreciation from community notables and religious leaders, the 
occasional donations from wealthy supporters such as the Rothschilds, nor subventions from the Kultusgemeinde were sufficient to keep it solvent, and by the time of Kellner's departure for Czernowitz in 1904 its survival was in doubt. It had been kept afloat to that point solely by the generosity of the pioneering electrical engineer and industrialist Johann Kremenezky, founder of the Jewish National Fund and a close friend of both Herzl and Kellner ${ }^{85}$ In late 1904, Bnai Brith in Vienna stepped in, rescuing Toynbee Hall by taking it over entirely. ${ }^{86}$ The new management pushed aside the Zionists but was otherwise scrupulous in maintaining continuity, and Bnai Brith's deep pockets allowed Toynbee Hall to flourish over the next decade. These were its most successful years. Annual visitor numbers increased to an average of 35,000 by 1910 , an additional branch was opened in the city in order to reach a wider audience, and in November 1914 it moved to its own premises. ${ }^{87}$

If in Germany, Vienna, and Prague it was Bnai Brith that sustained and developed the Toynbee Halls-more were opened, for example, in Frankfurt, Mannheim, Breslau, and Munich-this was not the case further east, where the Zionist movement retained control ${ }^{88}$ But in east-central Europe, too, there was a Bnai Brith dimension, albeit minor by comparison. Here, the organization provided support rather than leadership, a function of the greater degree of mutual accommodation between Jewish nationalism and Bnai Brith in this region than in Germany or Vienna. In Berlin and Vienna, Zionists had expressed irritation at their exclusion from the Toynbee Halls following Bnai Brith's takeover ${ }^{89}$ In eastern Europe, by contrast, personal and institutional links between the two movements were not uncommon. One of the founders of the Jewish Toynbee Hall in Iaşi, Romania, for example, a Zionist-run operation from its opening in 1906 until World War I, was Jacob Niemirower, not only a committed Zionist but also in the interwar years the first chief rabbi of Romania and president of Bnai Brith in Romania. ${ }^{90}$ In Galicia, which became the stronghold of the Toynbee Hall movement, Zionist sponsorship and leadership similarly remained clear, but in both Lwów and Kraków, home to the two largest Toynbee Halls in the province, there were significant links between Zionism and Bnai Brith, particularly in the period of the Polish Republic. Rabbi Ozjasz Thon, for example, whose Yiddish-language pamphlet on the Jewish Question was published by the Toynbee Halls, was a leader of both the Zionist movement and Bnai Brith in Kraków. ${ }^{91}$ Despite irreconcilable ideological differences, the two movementswith their shared belief in Jewish unity, allied with a powerful sense of responsibility for the welfare of the less fortunate-found a modicum 
of common purpose in the neutral space of the Jewish Toynbee Hall. It was, said a Berlin Bnai Brith leader in 1904, the organization's "favorite child," and in Prague Bnai Brith later claimed exclusive patrimony, describing Toynbee Halls as the "purest expression of the Bnai Brith idea." "F2 For their part, Zionists celebrated their achievement in creating a "model institution" that had enjoyed a "triumphal march through the entire Jewish world. ${ }^{\prime 3}$ Success has many fathers.

This "triumphal march" was most evident in Galicia, where the Zionists hoped to make each Toynbee Hall a People's House (Volksheim), a focal point of the crowded landscape of libraries, reading rooms, and cultural venues. In Lwów, home to one of the first Jewish Toynbee Halls, this was proclaimed at the very outset. ${ }^{94}$ It was seen as the Jewish counterpart to the "People's Houses" created by Polish and Ruthenian nationalists in Galicia, part of the process of carving out separate ethnic public spheres in the province. ${ }^{95}$ From the Zionist perspective, as already noted, Toynbee Halls had a role to play in the movement's strategy of conquering the communities. By 1904, Toynbee Halls were already being described as "the most important step" in this process, "true People's Houses and nurseries of national life."

This was not an entirely vain boast. The Lwów Toynbee Hall recorded some 10,000 attendees at its events in 1904 and branched out by publishing pamphlets on prostitution and tuberculosis (both seen as issues of particular relevance for eastern European Jewry) and by supporting a gymnastic association and choir. By 1913, annual attendance had risen to more than $18,000 .{ }^{97}$ Kraków's Toynbee Hall opened in late 1905-four others already existed, in Lwów, Tarnopol, Brody, and Zbarasz-and by 1913 had three thousand members. During that year, its nightly lectures (in Polish and Yiddish), along with its concerts, children's parties, and adult-education courses, attracted more than 15,000 visitors. ${ }^{98}$ An Association of Jewish Toynbee Halls in Galicia was created in 1907 to coordinate the work of its affiliates, most of which were in eastern Galicia. Three years later, the association claimed an audience of 100,000 people annually, and in 1913 it reported that 20 of the 25 Toynbee Halls in Galicia were members. ${ }^{99}$ Still further east was the most successful of all Jewish Toynbee Halls, in Czernowitz. The city's first Toynbee Hall opened in 1902 but soon ran aground. In early 1911, Kellner-who, it will be recalled, had moved there in 1904 to take up a university post and was now also a regional parliamentarian-initiated a relaunch. ${ }^{100}$ In Czernowitz, he found the financial support that had been lacking in Vienna and succeeded in creating something close to the "ideal type" of Toynbee Hall that he had always envisaged-"a hub," as he described it, "of national 
and cultural life."101 In late 1913 he presided over the opening of purpose-built premises that soon housed a range of institutions and services: an apprentice home, a day-care center for children, a credit cooperative, an employment agency, a legal-advice bureau, as well as newspaper and political offices. ${ }^{102}$ This was indeed a People's House.

By 1914, Jewish Toynbee Halls were flourishing. If they had not, as an enthusiastic observer claimed, "conquered the entire continent," they had nevertheless established a secure niche in the cultural and social landscape of Jewish society in east-central Europe ${ }^{103}$ This proved, though, to be their zenith, as they were not able, collectively or individually, to withstand the catastrophic consequences of World War I and its aftermath. Their trajectory in the radically changed circumstances of the 1920s and 1930s was one of instability and decline, as the educational, social, and welfare needs that they addressed were increasingly met in more professional and systematic fashion, whether by states or political movements. What had worked well in 1910 was less effective in 1930.

Adult education, for example, expanded rapidly in interwar Austria and Germany, led by the state and by political movements, and philanthropic bodies like Bnai Brith could not begin to match their resources. ${ }^{104}$ Vienna's Toynbee Hall operated on a much-reduced scale during the war years, its activity curtailed by the exigencies of war, severe restrictions on associational life, and the pressures imposed by an acute refugee crisis. ${ }^{105}$ With the collapse of the Habsburg state and the chaos of the immediate postwar years in the new Austrian republic, which were marked by political instability, economic distress, and food shortages, this Toynbee Hall subsided into inactivity. Resuming in 1921, it followed the same template as ever but could not fully regain its lost momentum. The end came in the summer of 1939, when the Nazi authorities dissolved it and confiscated its assets. ${ }^{106}$ In Prague, similar wartime difficulties-among them an influx of Jewish refugees from Galicia-led to the suspension of Toynbee Hall's activity in 1915. A fresh start was made in 1923, with aspirations of expansion and independence from Bnai Brith, but it does not appear to have survived beyond the mid-1930s. ${ }^{107}$ In Weimar Germany, the rapid growth of adult education was reflected in Jewish society, with new initiatives such as the Lehrhaus movement that built on and surpassed the Toynbee Halls. Berlin's Toynbee Hall carried on, although no longer on the same scale as previously, eventually to be "dissolved and prohibited" by the Nazi regime in 1937. ${ }^{108}$ In Frankfurt, Bnai Brith restarted its Toynbee Hall, closed before the war, as part of a community welfare "emergency campaign" in late 1931; it remained open until 1938. ${ }^{109}$ 
[68] In its genesis the Jewish Toynbee Hall was unusual, a composite of late-Victorian English reformist enthusiasm, late-imperial Austrian

Jewish

Social

Studies

Vol. 24

No. 3 Zionism, and deep-seated Jewish traditions of education and sociability. Its historical trajectory, though, was familiar: it flourished in the first decade of the twentieth century, faded abruptly in World War I and the immediate postwar years, and, in Germany and Austria, was destroyed by the Nazi regime in the late 1930s. Its east/ west divergence was familiar also; this was a nationalist initiative that was salvaged by antinationalists in western Austria and Germany but remained in Zionist hands in Galicia, Bukovina, and Romania. In Berlin, Vienna, and Prague, Toynbee Halls became a valuable part of Bnai Brith's extensive philanthropic and educational network; in Galicia and Bukovina, they constituted a core element of the Zionist movement's cultural work. In both east and west, they were pioneers of secular Jewish adult education, attracting hundreds of thousands of women and men to lectures and courses and acquainting them with the diversity and depth of Jewish history and culture. Nationalists and nonnationalists alike agreed that assimilation posed a mortal threat to Jewish life and were united in their wish to reinforce individual and collective Jewish consciousness on as broad a basis as possible.

Toynbee Halls became, as noted, a significant part of the Jewish public sphere in Europe, a dense web of associational life that-in a crude but serviceable generalization-tended to take religious and ethnic forms in western Europe and more overtly nationalist shape in eastern Europe. In the former, this has been called a "subculture"; in the latter, it constituted one ethnic or national milieu among many. ${ }^{110}$ In both east and west, the extent and dynamism of this public sphere were a function of the coexistence (and sometimes the collision) of two forces. On the one hand, it was generated from within Jewish society by a will to collective self-assertion for reasons already alluded to; on the other, it developed in response to the barriers to integration in the surrounding societies, in which antisemitism and exclusion were a fact of life. This is particularly clear in the Habsburg Austrian context, out of which the Jewish Toynbee Hall idea emerged. It was made possible by a partially liberal state and a civil society with a measure of political and cultural pluralism; it was made necessary by the constraints imposed by the Jewish Question and almost endemic ethnic and national frictions. As the Viennese Jewish writer Arthur Schnitzler wrote in 1912, "it was not possible, especially not for a Jew in public 
life, to ignore the fact that he was a Jew; nobody else was doing so, not the Gentiles and even less the Jews." 111

It was precisely this heightened visibility that led Kellner to create the Jewish Toynbee Hall, in order to skirt what he feared would be the inevitable antisemitic reaction in Vienna to Jews establishing a Toynbee Hall aimed at the general public. This drew together the central threads of Kellner's political and cultural work in an ambitious social and cultural experiment, uniting his lifelong Anglophilia with his enduring commitments to social reform, liberal nationalism, and education. Spreading east and west, it became one of his signal contributions to the Zionist movement and to Jewish society more generally, on a par with his role as Herzl's comrade-in-arms and later as regional parliamentarian and leader of Bukovina Zionism. London's Toynbee Hall has received its share of attention from historians, but the same cannot be said for its Jewish offspring in central and eastern Europe, an unfinished story that left few traces. Its historiographical restoration, along with that of its creator Leon Kellner, is long past due.

\section{Notes}

1 "Die Eröffnung der ersten 'jüdischen Toynbeehalle' in Wien," Die Welt, Dec. 7, 1900, pp. 12-13. See also Rosa Feigenbaum, "Die Eröffnung der ersten jüd. Toynbeehalle in Wien am 2. December 1900," Die Neuzeit, Dec. 7, 1900, p. 515; "Eine Toynbee-Halle," Neues Wiener Tagblatt, Dec. 4, 1900, pp. 6-7; and Leon Kellner, Eine jüdische Toynbee-Halle in Wien (Vienna, 1902), 7.

2 L. Kellner, Eine jüdische Toynbee-Halle, 10-11.

3 Michael A. Meyer, ed., German Jewish History in Modern Times, Volume 3: Integration in Dispute, 1871-1918 (New York, 1997), 154.

4 Albrecht Hellmann [Siegmund Kaznelson], "Die Geschichte der österreichisch-jüdischen Kongressbewegung: Zur Frage der nationalen Minderheitsrechte der Juden," Der Jude 5 (1920-21): 394.

5 I use Habermas's familiar "public sphere" here in a loose descriptive sense. See Harold Mah, "Phantasies of the Public Sphere: Rethinking the Habermas of Historians," Journal of Modern History 72 (2000): 153-82, and Craig Calhoun, ed., Habermas and the Public Sphere (Cambridge, Mass., 1992).

6 On Germany, see for example David Sorkin, The Transformation of German Jewry, 1780-1840 (Oxford, 1987). On Russia, see Jeffrey Veidlinger, Jewish Public Culture in the Late Russian Empire (Bloomington, Ind., 2009). 
7 Pieter Judson, Exclusive Revolutionaries: Liberal Politics, Social Experience, and National Identity in the Austrian Empire, 1848-1914 (Ann Arbor, Mich., 1996), 18-25; Helmut Rumpler and Peter Urbanitsch, eds., Die Habsburgermonarchie 1848-1918, Band VIII: Politische Öffentlichkeit und

Jewish Social Studies

Vol. 24 No. 3 Zivilgesellschaft (Vienna, 2006), especially the essays in part 1.

8 For partial accounts, see Dieter Oelschlägel, "Integration durch Bildung: Jüdische Toynbee-Hallen und Volksheime in Österreich und Deutschland im ersten Drittel des zwanzigsten Jahrhunderts," in Durchbrüche ins Soziale: Eine Festschrift für Rudolph Bauer, ed. Peter Hermann and Peter Szynka (Vienna, 2014), 102-39; Elisabeth Malleier, "Die jüdische Toynbee-Halle in der Wiener Brigittenau," Spurensuche 17, no. 1-4 (2006): 104-13; Joshua Shanes, Diaspora Nationalism and Jewish Identity in Habsburg Galicia (New York, 2012), 178-80; Klaus Hödl, Als Bettler in die Leopoldstadt: Galizische Juden auf dem Weg nach Wien (Vienna, 1994), 162-65; and Marsha L. Rozenblit, The Jews of Vienna, 1867-1914: Assimilation and Identity (Albany, N.Y., 1983), 66-67.

9 Arnold J. Toynbee, A Study of History, 12 vols. (London, 1934-61), 1: 82 n. 2, 90-91; 8: 274-75, 289-91. See also Oskar K. Rabinowicz, Arnold Toynbee on Judaism and Zionism: A Critique (London, 1974), and William H. McNeill, Arnold J. Toynbee: A Life (New York, 1990), 246-49.

10 Canon Barnett and Mrs. S. A. Barnett, Towards Social Reform (London, 1909), 252.

11 Ibid., 241. On Toynbee, see Alon Kadish, Apostle Arnold: The Life and Death of Arnold Toynbee, 1852-1883 (Durham, N.C., 1986).

12 Barnett and Barnett, Towards Social Reform, 240. See also Gareth Stedman Jones, Outcast London: A Study in the Relationship between Classes in Victorian Society (Oxford, 1971), and William Booth, In Darkest England and the Way Out (London, 1890).

13 Barnett and Barnett, Towards Social Reform, 270.

14 See Standish Meacham, Toynbee Hall and Social Reform, 1880-1914: The Search for Community (London, 1987), and Nigel Scotland, Squires in the Slums: Settlements and Missions in Late Victorian Britain (London, 2007), 27-53.

15 On the settlement movement, see Scotland, Squires in the Slums. For Baedeker, see Seth Koven, Slumming: Sexual and Social Politics in Victorian London (Princeton, N.J., 2004), 244. It made fewer inroads on the continent. See Stuart Marriot, English-German Relations in Adult Education, 1875-1955 (Leeds, 1995), 46-50, and Maria Dornseifer, "Geschichte der Settlements/Nachbarschaftsheime," in Geschichte der Erwachsenenbildung, ed. Franz Pöggeler (Stuttgart, 1975), 235-36. For Jewish analogs, see Sabine Haustein and Anja Waller, "Jüdische Settlements in Europa: Ansätze einer transnationalen sozial-, geschlechter- und ideenhistorischen Forschung," Medaon 3 (2009): 1-14.

16 Jeffrey Scheuer, "Legacy of Light: University Settlement's First Settlement," in Legacy of Light: University Settlement, 1886-2011 (New York, 2012), 50. 
17 Koven, Slumming, 250, and see 247-48. For "mother of all settlements," see, for example, Scotland, Squires in the Slums, 27, 52.

18 See Geoffrey Ginn, Culture, Philanthropy and the London Poor, 1880-1900 (Abingdon, 2017), 19-37, 68-107.

19 Emma Goldman, Living My Life (New York, 1931), 160.

20 Emily K. Abel, "Canon Barnett and the First Thirty Years of Toynbee Hall” (Ph.D. diss., University of London, 1969), 121-22; David Feldman, "Mr Lewinstein Goes to Parliament: Rethinking the History and Historiography of Jewish Immigration," East European Jewish Affairs 47 (2017): 138-39; idem, Englishmen and Jews: Social Relations and Political Culture, 1840-1914 (New Haven, Conn., 1994), 166-72.

21 "East End Poverty," Jewish Chronicle, Aug. 25, 1893, pp. 9-10.

22 “A Jewish Toynbee Hall," Jewish Chronicle, Feb. 16, 1894, pp. 12-13. See also "Notes of the Week," Jewish Chronicle, Jan. 6, 1893, pp. 5-6, and Asa Briggs and Anne Macartney, Toynbee Hall: The First Hundred Years (London, 1984), 28.

23 Theodor Herzl, diary entry, Nov. 24, 1895, in Briefe und Tagebücher: Zionistisches Tagebuch, 1895-1899, ed. Alex Bein et al., 7 vols. (Berlin, 1983-96), 2: 280.

24 "The Minister and the Mission," Jewish Chronicle, Nov. 14, 1890, p. 6. On Montagu, see Daniel Gutwein, The Divided Elite: Economics, Politics and Anglo-Jewry, 1882-1917 (Leiden, 1992), 145-306, and Eugene C. Black, The Social Politics of Anglo-Jewry, 1880-1920 (Oxford, 1988), 14-19.

25 "The Home and Hospital for Jewish Incurables," Jewish Chronicle, Oct. 13, 1893, p. 14. For Adler, see also "The Chief Rabbi on the Unemployed," Jewish Chronicle, Feb. 2, 1894, p. 9. Montagu later turned against the idea in its original form ("East End Scheme," Jewish Chronicle, Jan. 17, 1896, p. 10; "Federation of Synagogues," Jewish Chronicle, Jan. 31, 1902, p. 25).

26 "Notes of the Week," Jewish Chronicle, June 2, 1893, p. 5.

27 "East End Poverty," Jewish Chronicle, Aug. 18, 1893, pp. 8-9. See also "Jewish Toynbee Hall," 12-13.

28 On the East End Scheme, see Gutwein, Divided Elite, 145-306.

29 Leon Kellner, "Yarmouth," Neue Freie Presse, Oct. 3, 1891, pp. 1-3.

30 Leon Kellner, "Wie man in London die Massen erzieht," Neue Freie Presse, July 12, 1895, pp. 1-5. See also Leon Kellner, Ein Jahr in England (Stuttgart, 1900), 225-48.

31 Accounts of Kellner's life can be found in Anna Kellner, Leon Kellner: Sein Leben und sein Werk (Vienna, 1936); Shmuel Spann, "Dr Leon Kellner," in Torne: Kiem un hurbn fun a yidisher shtot, ed. Avraham Chomet (Tel Aviv, 1954), 270-81; and Paula Arnold, Zikhronot be-ahavah (Jerusalem, 1958). For Tarnów's population, see Jakob Thon, Die Juden in Oestereich (Berlin, 1908), 17, 20; Felix A. Theilhaber and Herbert Philippsthal, "Statistik der Juden: Bevölkerungsstatistik," Jüdisches Lexikon: Eine enzyklopeädisches Handbuch des jüdischen Wissens, ed. Georg Herlitz and Bruno Kirschner, 4 vols. (Berlin, 1927-30), 4/2: 649; and Franczisek Herzig, "Tarnów od r. 1567 do r. 1907," in Dzieje miasta 
Tarnowa, ed. Jan Leniek, Franczisek Herzig, and Franczisek Leśniak (Tarnów, 1911), 187, 250.

32 Three in every thousand members of the school-age population in Austria attended secondary school in 1880 , whereas 5.15 per thousand of those aged 19-22 made it to university. Jews made up nearly 15 percent of secondary-school pupils, more than three times their proportion of the population, and constituted between 15 and 20 percent of university students. See Gary B. Cohen, Education and MiddleClass Society in Imperial Austria, 1848-1918 (West Lafayette, Ind., 1996), 56, table 2/1, 145, 277, table 4, and idem, "The Politics of Access to Advanced Education in Late Imperial Austria," Center for Austrian Studies Working Paper 93-6, Sept. 2002, https://conservancy.umn.edu /bitstream/handle/11299/90582/1/WP936.pdf.

33 A. Kellner, Leon Kellner, 17, 117.

34 Kellner-Professorenakt-18771, 1890, University of Vienna, Allgemeines Verwaltungsarchiv, Österreichisches Staatsarchiv Vienna, Austria (hereafter AVA); A. Kellner, Leon Kellner, 26-27.

35 On the Schopenhauer piece, published in Deutsche Wochenschrift, see Marburger Zeitung, Feb. 29, 1884, p. 4, and A. Kellner, Leon Kellner, 29. For the others, see Leon Kellner, "Zur zweihundertjährigen Todesfeier Peter Corneilles," Die Presse, Oct. 1, 1884, pp. 1-3; idem, "Jacques Bonhomme in der Literatur," Die Presse, Mar. 5, 1885, pp. 1-2.

36 P. W., "Leon Kellner gestorben," Neue Freie Presse, Dec. 6, 1928, p. 7.

37 A list of his works can be found in "Kellner, Leon," Lexikon deutschjüdischer Autoren, ed. Renate Heuer, 21 vols. (Munich, 1992), 13: 349-57.

38 Shaw described Kellner as a "strong-minded ... well-informed ... man of infinite resource. He talked English literature (about which he knew more than any of us)." See Bernard Shaw, "A Devil of a Fellow: SelfCriticism," Shaw: The Journal of Bernard Shaw Studies 20 (2000): 249-50. For Macdonald, see Briggs and Macartney, Toynbee Hall, 55.

39 Leon Kellner to Theodor Herzl, Feb. 18, 1899, H1/1455-17, Central Zionist Archives, Jerusalem, Israel (hereafter CZA); Kellner-Personalakt, 2172/zl.709, University of Vienna, Archiv der Universität Wien, Austria.

40 "Dekanat der philosophischen Fakultät [Prof. Carl Zelinka] an das K.K. Ministerium für Kultus und Unterricht," Dec. 12, 1901, ProfessorenaktCzernowitz-Kellner, AVA; “Amtliche Teil,” Wiener Zeitung, Mar. 8, 1904, p. 1.

41 See, for example, "Concordia-Ball," Neues Wiener Tagblatt, Feb. 26, 1908, p. 7; "Hof- und Personalnachrichten," Neues Wiener Tagblatt, July 3, 1912, p. 12; "Literarische Notizen," Neue Freie Presse, Jan. 6, 1901, p. 32; G. A. Crüwell, "Die viktorianische Literatur," Neue Freie Presse, July 4, 1909, pp. 33-35; Neue Freie Presse, Nov. 23, 1913, pp. 34-35; "Literarische Notizen," Wiener Zeitung, Nov. 25, 1905, p. 8; and "Literaturgeschichte," Wiener Zeitung, July 7, 1910, p. 6.

42 Leon Kellner, "Shakespeare and Pirque Aboth," Dec. 1922, 0119 916, Schwadron Archive, National Library of Israel, Jerusalem; "Shakespeare and the Talmud," Jewish Chronicle, May 22, 1925, p. 34. 
43 Theodor Herzl, diary entry, Mar. 26, 1898, in Briefe und Tagebücher, 2: 578. For his part, Kellner wrote: "I was for many years satisfied with one friend, my wife; Zionism brought me another, you." Leon Kellner to Theodor Herzl, Feb. 2, 1899, H1/1455-17, CZA.

44 Theodor Herzl, diary entries, May 13 and 15, 1897, in Briefe und Tagebücher, 2: 510-11; Theodor Herzl to Leon Kellner, Feb. 15, 1899, H1/2605, CZA. Kellner initially declined but later took on the post. On the Judenstaat translation, see Theodor Herzl to Leon Kellner, Mar. 4, 1896, H1/2605, CZA.

45 On the Neue Freie Presse post, see Theodor Herzl to Leon Kellner, Jan. 10, 1899, H1/2605, CZA. For Altneuland, see Theodor Herzl to Leon Kellner, July 26, 1900, H1/2605, CZA.

46 Kellner to Herzl, Feb. 2, 1899.

47 For "impractical," see Theodor Herzl to Leon Kellner, Nov. 21, 1898, A71/33-4, CZA; for the 1897 elections, see Theodor Herzl, diary entries, Jan. 29 and Feb. 5, 1897, in Briefe und Tagebücher, 2: 480-81; for diplomacy, see Theodor Herzl to Leon Kellner, Feb. 14, 1898; Mar. 18, 1899; Apr. 13, 1899; Dec. 31, 1900, H1/2605, CZA.

48 Theodor Herzl, diary entry, May 12, 1898, in Briefe und Tagebücher, 2: 584. See also Leon Kellner, "Zionistisches Streberthum,” Die Welt, Mar. 8, 1901, pp. 5-6, for Kellner's reservations about political engagement.

49 Shanes, Diaspora Nationalism, 49-50, 192-96; Adolf Gaisbauer, Davidstern und Doppeladler: Zionismus und jüdischer Nationalismus in Österreich, 18821918 (Vienna, 1988), 451-523.

50 A. Kellner, Leon Kellner, 60-61.

51 Ibid.

52 “Theodor Herzl-Trauerfeier," Czernowitzer Allgemeine Zeitung, July 6, 1907, p. 3.

53 "Misswirtschaft," Der Jüdische Volksrat, Dec. 1, 1911, pp. 1-2.

54 Leon Kellner, Shakespeare-Wörterbuch (Leipzig, 1922); idem, Restoring Shakespeare: A Critical Analysis of the Misreadings in Shakespeare's Works (London, 1925). A third was published posthumously: Leon Kellner, Erläuterungen und Textverbesserungen zu vierzehn Dramen Shakespeares (Leipzig, 1931). On universities in postwar Austria, see Ramon Pils, "Disziplinierung eines Faches: Zur Englischen Philologie in Wien im frühen 20. Jahrhundert," in Reflexive Innensichten aus der Universität: Disziplinengeschichten zwischen Wissenschaft, Gesellschaft und Politik, ed. Karl Anton Fröschl et al. (Vienna, 2016), 543-48, and Kurt Scharr, "'Eine überaus peinliche Lage': Die deutschsprachigen Professoren der Czernowitzer Universität zwischen Exil und Neuanfang, 1914-1920,” in Mutter: Land_Vater: Staat: Loyalitätskonflikte, politische Neuorientierung und der Erste Weltkrieg im österreichisch-russländischen Grenzraum, ed. Florian Kührer-Wielach and Markus Winkler (Regensburg, 2017), 167-91.

55 Präsidentschaftskanzlei to Leon Kellner, Nov. 27, 1919, Bestand 01, Präsidentschaftskanzlei (hereafter PK), 3007, Archiv der Republik, Vienna, Austria (hereafter AdR). 
56 Michael Hainisch, 75 Jahre aus bewegter Zeit (Vienna, 1978), 45, 229. On the Hofrat title, see President Hainisch to Dr. Emil Schneider (Minister für Unterricht), July 31, 1923, Bestand 01, PK, 5036, AdR; "Verleihung des Titels eines Hofrats,” Aug. 24, 1923, Bestand 01, PK, 5473, AdR.

Jewish

Social Studies

Vol. 24

No. 3 See also Franz Adlgasser, American Individualism Abroad: Herbert Hoover, die American Relief Administration und Österreich, 1919-1923 (Vienna, 1993).

57 Die jüdische Toynbee-Halle in Wien im zweiten Jahre ihres Bestehens (Vienna, 1902), 9. In July he had urged delegates to the Zionist Congress to be held in London in August to visit Toynbee Hall: Leo Rafaels [Leon Kellner], "Was wir in London sehen sollen," Die Welt, July 27, 1900, pp. 2-3. See also Hermann Berliner, "Jüdische Toynbee-Halle in Wien," Die Wahrheit, Nov. 29, 1901, pp. 3-4, and Malleier, "Die jüdische Toynbee-Halle," 105.

58 Nearly 150,000 Jews lived in Vienna in 1900, of whom perhaps one quarter were Galician-born. See Ivar Oxaal and Walter W. Weitzmann, "The Jews of Vienna: An Exploration of Basic Social Dimensions," Leo Baeck Institute Year Book 30 (1985): 398, 400. On their poverty, see Rozenblit, Jews of Vienna, 36-37.

59 Kellner was active in Fabianist circles in Vienna: see A. Kellner, Leon Kellner, 84-85, and Eva Holleis, Die Sozialpolitische Partei: Sozialliberale Bestrebungen in Wien um 1900 (Munich, 1978), 9-14.

60 Berliner, "Jüdische Toynbee-Halle in Wien," 3-4. See also Shmuel Almog, Zionism and History: The Rise of a New Jewish Consciousness (New York, 1987), 188-93.

61 L. Kellner, Eine jüdische Toynbee-Halle, 5-7.

62 Leo Rafaels [Leon Kellner], "Eine jüdische Toynbee-Halle in Wien," Die Welt, Oct. 19, 1900, p. 2. See also L. Kellner, Eine jüdische Toynbee-Halle, $10-11$.

63 The first quotation is from "Die Eröffnung der ersten "jüdischen Toynbeehalle' in Wien," 13, and the second from Rafaels, "Eine jüdische Toynbee-Halle in Wien," p. 1.

64 Quotation in Rafaels, "Was wir in London sehen sollen," 3. See also "Aufruf!," Die Welt, Nov. 16, 1900, p. 8.

65 Die jüdische Toynbee-Halle in Wien im zweiten Jahre, 21; L. Kellner, Eine jüdische Toynbee-Halle, 10.

66 L. Kellner, Eine jüdische Toynbee-Halle, 12-13. On this aspect of Vienna, see Klaus Hödl, Zwischen Wienerlied und Der Kleine Kohn: Juden in der Wiener populären Kultur um 1900 (Göttingen, 2017).

67 Hans Altenhuber, Universitäre Volksbildung in Österreich, 18951937 (Vienna, 1995), 15-21; Wolfgang Seitter, Geschichte der Erwachsenenbildung: Eine Einführung (Bielefeld, 2007), esp. 99-116.

68 Michael Brenner, The Renaissance of Jewish Culture in Weimar Germany (New Haven, Conn., 1996), 69-99; Steven E. Aschheim, Brothers and Strangers: The East European Jew in German and German Jewish Consciousness, 1800-1923 (Madison, Wisc., 1982), 193-97. 
69 Die jüdische Toynbee-Halle in Wien im zweiten Jahre, 29-30; L. Kellner, Eine jüdische Toynbee-Halle, 22-23; Jahresbericht der jüdischen Toynbee Halle in Wien, 1904 (Vienna, 1904), 6.

70 "Jüdische Toynbee-Hallen in Brünn und Drohobycz," Die Welt, Feb. 15, 1901, p. 11; "Von unserer westlichen Volksbildungs-Bewegung," Die Welt, Oct. 4, 1901, p. 13; Leo Rafaels, "Die Wiener Toynbee-Halle im dritten Jahre," Die Welt, Feb. 20, 1903, pp. 4-5; Hermann Berliner, "Jüdische Toynbee-Halle in Wien," Die Wahrheit, Mar. 8, 1901, p. 7; L. Kellner, Eine jüdische Toynbee-Halle, 7.

71 Die jüdische Toynbee-Halle in Wien im zweiten Jahre, 24-37; Jahresbericht der jüdischen Toynbee Halle in Wien, 1904, 7-12, 21-23; L. Kellner, Eine jüdische Toynbee-Halle, 14-17, 22-23; "Die jüdische Toynbee-Halle," Die Welt, Apr. 26, 1901, p. 12; Rafaels, "Die Wiener Toynbee-Halle im dritten Jahre," 5; "Oesterriech-Ungarn," Die Welt, Feb. 27, 1903, p. 9.

72 L. Kellner, Eine jüdische Toynbee-Halle, 9-10; Die jüdische Toynbee-Halle in Wien im zweiten Jahre, 22.

73 Die jüdische Toynbee-Halle in Wien im zweiten Jahre, 4, 22, 37-41 (quotation on 22); Jahresbericht der jüdischen Toynbee Halle in Wien, 1904, 12, 17-20, 24-26. The mixed picture with regard to the role of women is discussed in Malleier, "Die jüdische Toynbee-Halle," 106-8; idem, "Gegen den fremden Kontinent der Armut: Die Anfangsjahre der 'Jüdischen Toynbehalle' in der Wiener Briggitenau," Das jüdische Echo 54 (2005): 113-14.

74 For Brno and Drohobycz, see "Erste jüdische Toynbee-Halle in Wien," Die Welt, Jan. 25, 1901, p. 14; "Jüdische Toynbee-Halle in Brünn," Die Welt, Feb. 1, 1901, p. 15; "Jüdische Toynbee-Halle in Drohobycz," Die Welt, Feb. 8, 1901, p. 12; and "Jüdische Toynbee-Hallen in Brünn und Drohobycz," 11. For Braila, see "Jüdische Toynbee-Halle in Braila," Die Welt, Mar. 8, 1901, p. 14. For Prague, see "Vereinsnachrichten," Prager Tagblatt, Feb. 15 1902, p. 5; "Vorträge," Prager Tagblatt, Mar. 30, 1902, p. 7; "Jüdische Toynbee-Hallen in Brünn und Drohobycz," 11; and "Eine Toynbee-Halle in Prag," Die Welt, Feb. 7, 1902, p. 12. For Bucharest, see "Toynbee-Halle in Bukarest," Die Welt, Mar. 14, 1902, p. 14. For Lemberg, see "Jüdische Toynbee-Halle in Lemberg," Die Welt, Nov. 1, 1901, p. 12; "Brief aus Lemberg," Die Neuzeit, Nov. 15, 1901, pp. 466-67; and "Brief aus Lemberg," Die Neuzeit, Apr. 18, 1902, p. 166. For Amsterdam, see "The Jewry of the Netherlands," Jewish Chronicle, Aug. 22, 1902, p. 16, and Stenographisches Protokoll der Verhandlungen des V. Zionisten Congresses (Vienna, 1901), 17-18. For Czernowitz, see "Aus den Vereinen," Die Welt, Nov. 1, 1901, p. 12, and "Toynbee-Halle in Czernowitz," Die Welt, Feb. 14, 1902, p. 15. For Berlin, see "Eine Toynbee-Halle in Berlin,” Die Welt, Feb. 1, 1901, pp. 14-15; "Aus der Bewegung," Israelitische Rundschau, Jan. 17, 1902, p. 5; and Otto Warburg, "Kommision zur Vorbereitung einer Toynbee Hall in Berlin," 1902, A12/50, CZA.

75 For the Israelitische Gemeinschaftshaus (Israelite Community Center) in Hamburg, see Louis Maretzki, Geschichte des Ordens B'nai B'riss in 
Deutschland, 1882-1907 (Berlin, 1908), 241; Erika Hirsch, Jüdisches Vereinsleben in Hamburg bis zum Ersten Weltkrieg (Frankfurt, 1996), 98-99; and Oelschlägel, "Integration durch Bildung," 114.

76 On Bnai Brith, see Katerina Capkova, "Jewish Elites in the 19th and 20th Centuries: The B'nai B'rith Order in Central Europe," Judaica Bohemiae

Jewish 36 (2000): 119-42, and Andreas Reinke, "Eine Sammlung des jüdischen Bürgertums': Der unabhängige Orden B'nai B'rith in Deutschland," in Juden, Bürger, Deutsche: Zur Geschichte von Vielfalt und Differenz, 18001933, ed. Andreas Gotzmann, Rainer Liedtke, and Till van Rahden (Tübingen, 2001), 315-40.

77 "Vorträge," 7; "Prag," Die Wahrheit, Dec. 26, 1902, p. 7; Katerina Capkova, Czechs, Germans, Jews? National Identity and the Jews of Bohemia (New York, 2012), 89. On Bendiener and Falkowicz, see Gary B. Cohen, The Politics of Ethnic Survival: Germans in Prague, 1861-1914 (West Lafayette, Ind., 2006), 109, 131-32, 163.

78 Gustav Haas, "Toynbehalle," B'nai B'rith: Monatsblätter der Großloge für den Čechoslovakischen Staat 1, no. 6 (June 1922): 127; "Jüdische Toynbeehalle Prag," Prager Tagblatt, Apr. 28, 1906, p. 23; July 1, 1906, p. 46; Mar. 30, 1913, p. 34; Franz Kafka, Tagebücher, Volume 2: 1912-1914, ed. Hans-Gerd Koch (Frankfurt, 1994), 215-16.

79 Bericht über das erste Betriebsjahr der jüdischen Toynbeehalle der Berliner BneiBriss-Logen (12. Oktober 1904-30. März 1905), 19. See also Maximilian Stein, Zur Eröffnung der neuen Toynbee-Halle der Berliner Logen U.O.B.B (Berlin, 1909), 3-4.

80 Bericht über das erste Betriebsjahr, 19. On the social composition of the audiences, of whom one third were women, see Bericht über das erste Betriebsjahr, 22, 24, and Stein, Zur Eröffnung, 7-8.

81 Stein, Zur Eröffnung, 2-3; Jahresbericht der jüdischen Toynbee-Halle (für Volksbildung und Unterhaltung) der Berliner Bnei-Briss-Logen über das achte Betriebs-Jahr (1.11.1911 bis Ende März 1912), 3. On Kellner's influence on the founding of the Berlin Toynbee Hall, see Maximilian Stein, "Zur Begründung einer jüdischen Toynbee-Halle in Berlin (1904)," Vorträge und Ansprachen von Maximilian Stein (Frankfurt, 1929), 147-48.

82 Bericht über das erste Betriebsjahr, 32.

83 Stein, Zur Eröffnung, 5-6; Bericht über das fünfte Betriebsjahr der jüdischen Toynbeehalle der Berliner Bnei-Briss-Logen (19. Oktober 1908 bis Ende März 1909), 3.

84 Testimonies in Jahresbericht der jüdischen Toynbee-Halle (für Volksbildung und Unterhaltung) (1.11.1911-März 1912), 4-5; Jahresbericht der jüdischen Toynbee-Halle (für Volksbildung und Unterhaltung) der Berliner Bnei-Briss-Logen über das neunte Betriebs-Jahr (1.11.1912 bis Ende März 1913), 4-5.

85 Jahresbericht der jüdischen Toynbee Halle in Wien, 1904, 4, 14-15; "Aus der Wiener jüdischen Toynbee-Halle,” Die Welt, July 1, 1904, pp. 13-14. On Kremenezky, see Mascha Hoff, Johann Kremenezky und die Gründung des 
KKL (Frankfurt, 1986). For examples of support, see Die Neuzeit, Mar. 28, 1902, p. 131; "Die jüdische Toynbee-Halle" (Apr. 26, 1901), 12; "Die jüdische Toynbee-Halle in Wien," Die Welt, Nov. 6, 1903, pp. 8-9; and Jahresbericht der jüdischen Toynbee Halle in Wien, 1904, 34.

86 Ludwig Singer, "Toynbee-Halle und Kinderhort," in Festschrift anlässlich des fünfundzwanzigjährigen Bestandes des israel. Humanitätsvereines "Eintracht" (B'nai B'rith) Wien, 1903-1928 (Vienna, 1928), 72, 75-76; "Jüdische Toynbee-Halle," Die Welt, Nov. 11, 1904, p. 9; "Rund um die Toynbee-Halle," Die Wahrheit, Nov. 10, 1905, pp. 7-8.

87 Singer, "Toynbee-Halle und Kinderhort," 79-80; Jahresbericht der Jüdischen Toynbee Halle in Wien über die Vereinstätigkeit im Jahre 1907 (Vienna, 1908), 6-7; "Verschiedene Nachrichten," Die Wahrheit, Feb. 5, 1909, pp. 6-7; "Ein Jubiläum der Wiener Jüdischen Toynbee-Halle," Die Wahrheit, Dec. 9, 1910, pp. 9-10; "Jahresversammlung der 'Jüdischen Toynbee-Halle," Die Wahrheit, Mar. 20, 1914, pp. 5-6. On Bnai Brith in Vienna, see Denis B. Klein, Jewish Origins of the Psychoanalytic Movement (New York, 1981), 75-84, and Rozenblit, Jews of Vienna, 149-50.

88 For Frankfurt, see Jack Wertheimer, Unwelcome Strangers: East European Jews in Imperial Germany (New York, 1987), 154-55, and "Anstalten und Vereine," Gemeindeblatt der Israelitischen Gemeinde Frankfurt am Main, Nov. 1931, p. 67. For Mannheim, see Maretzki, Geschichte des Ordens, 241-42. For Breslau, see "Korrespondenzen," Jüdische Volksstimme, Nov. 1, 1908, p. 5, and "Korrespondenzen," Nov. 3, 1910, pp. 5-6. For Munich, see Haas, "Toynbehalle," 126, and "Die jüdische Toynbeehalle," Der Jüdische Volksrat, Nov. 14, 1913, pp. 1-2.

89 “Kleine Mitteilungen," Jüdische Rundschau, Nov. 10, 1905, pp. 588-89; "Rund um die Toynbee-Halle," 7-8.

90 “Aus der Bewegung," Die Welt, Mar. 23, 1906, p. 19; "Rümanien,” Die Welt, Feb. 21, 1913, pp. 246-47; J. Niemirower, "Ein Blick in die Geschichte der Juden Jassys," Jüdische Volksstimme, July 27, 1910, p. 1; Sep. 7, 1910, p. 2; Lucian-Zeev Herşcovici, "Iacob Isac Niemirower," The YIVO Encyclopedia of Jews in Eastern Europe, ed. Gershon Hundert, 2 vols. (New Haven, Conn., 2008), 2: 1268-69.

91 Anna Kargol, Zakon Synów Przymierza: Krakowska loża "Solidarność," 18921938 (Warsaw, 2013), 122-25; "Jüdische Toynbeehallen in Galizien," Die Welt, Nov. 21, 1913, p. 1598. For links between Bnai Brith and Zionism in Lwów, see Łukasz Tomasz Sroka, "Stowarzyszenie humanitarne 'Leopolis' we Lwowie (1899-1938): Głowne kierunki działalności," Kwartalnik Historyczny Rocznik 123 (2016): 57-58. For Toynbee Halls and Bnai Brith, see Marta Baer-Issachar, "Zionistische Kulturarbeit in Galizien,” Jüdische Rundschau, Oct. 28, 1904, p. 360. In Prague, too, these links were evident: see Capkova, "Jewish Elites," 134-36. For Germany, see Reinke, "Eine Sammlung," 333-34.

92 For Berlin, see Bericht über das erste Betriebsjahr, 4. For Prague, see Haas, "Toynbehalle," 126. 
93 "Rund um die Toynbee-Halle," 7. For "model institution," see Berliner, "Jüdische Toynbee-Halle in Wien" (Nov. 29, 1901), 4.

94 "Jüdische Toynbee-Halle in Lemberg," 12. For similar in Kraków, see I. R., "Eine jüdische Volkshochschule in Krakau: Ein Brief," Neue Jüdische

Jewish Monatshefte 1 (Feb. 10, 1917): 264-65.

95 Jerzy Potoczny, Oświata dorostych i popularyzacja wiedzy w plebejskich środowiskach Galicji doby konstytucyjnej, 1867-1918 (Rzeszów, 1998), 271-77; Dietlind Hüchtker, Geschichte als Performance: Politische Bewegungen in Galizien um 1900 (Frankfurt, 2014), 198-204, 235-44.

96 Baer-Issachar, "Zionistische Kulturarbeit in Galizien,” 360.

97 Ibid.; "Brief aus Lemberg," 166; "Jüdische Toynbeehallen in Galizien," 1598.

98 "Jüdische Toynbeehalle in Krakau," Die Welt, Feb. 10, 1905, p. 11; "Westgalizischer Distriktstag," Die Welt, Dec. 12, 1913, p. 1704; Shanes, Diaspora Nationalism, 179-80; I. R., "Eine jüdische Volkshochschule." See also Nahum Michael Gelber, Toledot ha-tenu'ah ha-tsiyonit be-Galitsiah, 2 vols. (Jerusalem, 1958), 2: 501.

99 Ibid., 556, 586; "Księga protokołów Zarządu glównego żyd. "Toynbeehali,"” 1910-11, K2/19, CZA; "Die jüdischen Toynbeehallen in Galizien," Die Welt, Mar. 28, 1913, pp. 411-12. For slightly different figures, see "Jüdische Toynbeehallen in Galizien," 1598.

100 "Jüdische Toynbeehalle," Czernowitzer Allgemeine Zeitung, Jan. 17, 1911, p. 4; "Brief aus der Bukowina," Die Welt, Feb. 23, 1912, pp. 241-42; "Jüdische Toynbeehalle," Dr. Bloch's Österreichische Wochenschrift, Feb. 23, 1912, p. 128. For the first attempt, see "Toynbee-Halle," Bukowinaer Post, Dec. 5, 1901, p. 4, and "Toynbee-Halle in Czernowitz," 15.

101 "Die jüdische Toynbeehalle," 2.

102 “Czernowitz," Die Welt, Oct. 31, 1913, p. 1503; "Eröffnung der 'Jüdischen Toynbeehalle in Czernowitz," Die Welt, Dec. 5, 1913, pp. 1667-68; "Bureau der unentgeltlichen Arbeitsnachweis," Czernowitzer Allgemeine Zeitung (Abendausgabe), Oct. 15, 1912, p. 3; "Jüdisches Lehrlingsheim," Czernowitzer Allgemeine Zeitung (Abendausgabe), Nov. 1, 1913, p. 4; "Die Eröffnungsfeier der Toynbeehalle," Czernowitzer Allgemeine Zeitung (Abendausgabe), Nov. 18, 1913, pp. 3-4.

103 "Ein neuartiges Volksheim in Lemberg," Das interessante Blatt, Oct. 28, 1909, p. 3.

104 Thomas Dostal, "Bildung zu 'Volkstum und Heimat' in der österreichischen Volksbildung der Zwischenkriegszeit" (Ph.D. diss., University of Vienna, 2017); Wolfgang Scheibe, "1919-1933: Weimarer Republik," in Pöggeler, Geschichte der Erwachsenenbildung, 69-78; Joachim Dikau, "Geschichte der Volkshochschule," in Pöggeler, Geschichte der Erwachsenenbildung, 111-31.

105 By early 1915, some 150,000 Galician and Bukovina Jews had fled to Vienna as the Russians advanced on the eastern front. See Beatrix Hoffmann-Holter, "Abreisendmachung": Jüdische Kriegsflüchtlinge in Wien, 
1914 bis 1923 (Vienna, 1995). For the situation in Vienna and Austria more generally, see Maureen Healy, Vienna and the Fall of the Habsburg Empire: Total War and Everyday Life in World War I (Cambridge, Engl., 2004), and John Deak and Jonathan E. Gumz, "How to Break a State: The Habsburg Monarchy's Internal War, 1914-1918," American Historical Review 122 (1917): 1105-36.

106 For the war and the 1920s, see Singer, "Toynbee-Halle und Kinderhort," 80-84. On the closure, see M. Abt. 119, A32-Gelöschte Vereine (Purged Associations), 2278/1926, Wiener Stadt- und Landesarchiv, Austria.

107 Gustav Flusser, "Die jüdische Toynbeehalle in Prag," B'nai B'rith: Monatsblätter der Großloge für den Čechoslovakischen Staat 2, no. 6 (June 1923), 141-43; idem, "Die Prager Toynbeehalle," B'nai B'rith: Monatsblätter der Großloge für den Čechoslovakischen Staat 5, no. 6 (June 1926): 173-75; Claire Morelon, "L’arrivée des réfugiés de Galicie en Bohême pendant la Première Guerre mondiale: Rencontre problématique et limites du patriotisme autrichien," Histoire@Politique 28 (Jan.-Apr. 2016): 5-18.

108 Jüdische Toynbee-Halle für Volksbildung und Unterhaltung der Berliner BneiBriss-Logen, circular, Dec. 1922, Berlin/DBe/4/497, Central Archives for the History of the Jewish People, Jerusalem, Israel; "Die Beschlagnahme des Vermögens der Bne Briss-Logen,” Die Stimme: Jüdische Zeitung, Dec. 29, 1937, p. 3; Oelschlägel, "Integration durch Bildung," 117. For Weimar Jewish adult education, see Brenner, Renaissance of Jewish Culture, 69-99.

109 "Anstalten und Vereine," 67; "Aus der sozialen Arbeit unserer Gemeinde," Gemeindeblatt der Israelitischen Gemeinde Frankfurt am Main, Dec. 1934, pp. 129-30; "Ferienspiele 1935," Gemeindeblatt der Israelitischen Gemeinde Frankfurt am Main, Sept. 1935, p. 513; "Arnold Lazarus Halle in Oktober," Gemeindeblatt der Israelitischen Gemeinde Frankfurt am Main, Nov. 1937, p. 15; "Veranstaltungen der Arnold Lazarus Halle," Gemeindeblatt der Israelitischen Gemeinde Frankfurt am Main, Apr. 1938, p. 27. It was known also as Arnold Lazarus Hall, in memory of the Bnai Brith leader and rabbi who had been head of the hall prior to World War I.

110 For subculture, see Sorkin, Transformation of German Jewry.

111 Arthur Schnitzler, My Youth in Vienna, trans. Catherine Hutter (London, 1971), 6.

DAVID RECHTER is a professor of Modern Jewish History at the University of Oxford. He is the author of The Jews of Vienna and the First World War (2001) and Becoming Habsburg: The Jews of Austrian Bukovina, 1774-1918 (2013). He is coeditor of the Leo Baeck Institute YearBook. david.rechter@orinst.ox.ac.uk 
Reproduced with permission of copyright owner. Further reproduction prohibited without permission. 